\title{
The construction of school-enterprise cooperation curriculum system under education mode of stratified higher vocational education
}

\author{
Xuefeng $\mathrm{Wu}^{1}$, Xiaojun $\mathrm{Lu}^{2, *}$ \\ ${ }^{1}$ Chongqing Information Technology College, 404000, 5China \\ ${ }^{2}$ Harbin University of Commerce, 150028, China
}

Keywords: Higher Vocational Education; Stratified teaching; Tissue professionalism; solution

\begin{abstract}
In order to achieve the purpose of teaching according to the students' aptitude, and the cultivation of directionatity, we have explored and practiced a feasible new teaching model of stratified classification. It has been widely praised by teachers and students, in the process school practice and has achieved goal teaching results, but it still has some shortcomings to solve and improve. This paper to course on the elaboration of the problems in the financial professional curriculum system under the new model and proposes effective and targeted solution.
\end{abstract}

\section{浅谈高职分层教育模式下校企合作课程体系的建设}

\author{
吴雪枫 ${ }^{1}$, 鲁啸军 ${ }^{2, *}$ \\ ${ }^{1}$ 重庆信息技术职业学院, 重庆 404000 \\ ${ }^{2}$ 哈尔滨商业大学，哈尔滨 150028
}

关键词: 高职教育; 分层教学;课程体系;职业精神

摘要: 为了达到因材施教、指向性的培养目的, 我们探索并实践了可行的分层分类教学新模 式。分层分类教学模式在校实践过程中获得了师生的广泛好评, 并取得了良好的教学成果; 与之同时也面临着众多问题亟待解决。本文着重从新模式下, 财经专业课程体系方面的问题 给予阐述, 并提出行之有效的一些针对性解决方案。

\section{1. 分层教育模式下现有课程体系面临的问题}

当前, 高职院校因招生等各个方面的原因普遍把自身人才培养的层次定位过高, 从而导致 开设的课程多、选用教材不合理、课程体系不合理; 同时高职高专国家规划的部分教材与高 职教育的实际情况、学情、人才定位不符, 与就业为导向的高职教学目标不符。具体表现为 以下几方面:

\section{1 专业课程开设过多与教学时间不匹配}

通过我们调研得出, 绝大多数高职院校财经类专业的专业课程在 15 门左右, 与之对应的 教学时间主要集中在第二至第五四个学期, 从而导致专业教学过于集中且教学任务繁重。为 了完成既定的教学任务就必须压缩单科课程的学时 (一般的课程为 48 学时, 重点课程 64 学 时), 如此课时量对于很多贯穿全专业的课程, 不足以让高职学生达到学懂、学精、会用的 程度, 最终的结果就出现学生理论知识似是而非, 动手能力浅尝则止。与高职院校培养应用 型技术人才的目标相去甚远。

\section{2 课程深度与学情不符、与定位不符}

高职院校鉴于生源和学制的问题，把培养目标定位为中、低端一线应用型人才是符合客观 事实的。在深刻解析专业的就业面向和岗位技能需求的基础上, 有针对性的开设课程和有针 
对性的删减跟专业能力有关但非当前阶段必备技能的课程, 是可行同时也是符合高职教育定 位的。

对于高职会计专业，其培养目标定位就是“财务会计”，是会计入门级、一线岗位，即只需 要学生必须具备处理企事业单位日常业务的账务能力, 不需要学生具备更加高深的预决算会 计、管理会计等晋升岗位的知识和技能。但实际教学过程中, 绝大部分的高职院校都开设了 如《管理会计》《财务管理》《国民经济核算》等高难度课程。

高职学生相对于本科生, 在基础知识、学习能力、学习主动性上都普遍性的有很大的差距。 鉴于此, 诸如《管理会计》《财务管理》 《国民经济核算》等高难度课程的开设不利于学生 的专业兴趣的培养，会打击学生的积极性、会加重学生对未来专业岗位的不自信。

\section{3 教材缺乏针对行业的分类性}

会计专业这种有历史，核心知识和技能变化不大的老专业，其教材一直都沿用了传统的教 育模式和教育手段（都是基础会计一财务会计一成本会计一税务会计一管理会计这种教学流 程）。在此传统模式下, 主要培养的是学生的财会通用理论和方法, 此方法是建立在学生成 为会计全才的前提下，主要对象是本科生而非高职生。

传统的培养流程和模式, 忽视了学生的实际工作需要。因为通用的会计理论和具体行业会 计方面是很大的不同，且不同行业之间的会计方法和理论也是有很大的不同。从而导致学生 毕业后面临所学非所用的监筴、导致就业后什么都不懂, 不得不重新开始学。

目前会计类高职教材很少有涉及具体行业的专用教材（如针对建筑行业、房地产行业、零 售业、物流业、制造业、服务业等）。这与会计行业本身的发展不匹配，与培养目标不匹配、 与以就业为导向的培养宗旨不匹配。

\section{4 现有教材体系所呈现的知识体系不完整}

高职院校培养的人才主要面向的是中小企业和微型企业，企业的规模决定了岗位分工的不 明确。这就要求高职院校会计专业毕业生不但要懂基本账务处理, 还必须要有跟税务、工商、 银行等职能部门良好沟通和处理相关事务的能力。但目前所有的专业教材在涉及相关职能部 门的知识方面都是空白。这加大了学生就业后的工作难度, 不利于学生的就业稳定, 也不利 于学校的社会评价和认知。

\section{5 职业精神体系化培养的欠缺}

财会工作对于职业精神的塑造有着非常严格的要求。现有的教材体系和教育模式只是口头 强调职业精神，对于如何培养、锻炼、养成职业精神没有系统的知识架构和培养模式，对于 会计的职业精神没有准确的体系化描述，没有形成系统的理论体系; 对于职业精神如何嵌入 会计的教学与实践实训中没有相关的专业教材。

由于专业教材在职业精神培养上知识的空白, 导致会计行业的职业精神一直就只能依靠执 教老师“言传身教”，这对当前学生状况来说，培养强度不够、影响力度不够、促动不够、重 试程度不够。这会导致学生重技能轻思想、会导致学生意识不到职业精神对其未来的职业晋 升、对其未来人生道路的影响。

\section{6 局部知识体系更新的滞后}

财会专业的核心理论是成固化状态，几十年来都没变过也不需要变化。但是财会专业所涉 及的会计准则、法律法规等部分知识却是随着经济形势的发展而变化, 且是频繁变化 (如税 法、经济法和地方政府的法规条例等）。这就需要相关教材必须及时的做出相应的更新或改 编。但实际上因为各种原因导致规划教材在更新上总是滞后于学生学习时的具体情况。 


\section{2. 针对课程体系现有问题的可行性解决方案}

鉴于前述六条当前的问题描述，我们结合实际的教改过程总结并提炼了一些实践证明行之 有效的一些解决方案, 具体内容如下:

\section{1 结合实际学情, 精准定位人才层次和培养目标以实现精准课程定位}

高职院校培养的人才是面向一线的应用型人才, 我们的培养目标是让学生能胜任“财务会计” 的工作，为学生毕业后五年内储备足够的岗位知识和技能，为五年后的职业晋升夯实根基。 结合财务会计的岗位技能需求分析，在课程体系上删减了不符合职业定位和岗位需求、不符 合当前学生学情状况的相关课程。如前所述的 《管理会计》 《财务管理》 《国民经济核算》 等, 与之对应的增加了具体的行业会计知识的专用教材（如零售会计、建筑会计、流通会计 等); 同时, 通过相关专业社团来增加一些不需要开设专业课程但又必备的一些技能培训（如 点钞、验钞、珠算、心算、键盘盲打等被普遍认为已经不需要的实操技能）。

整合知识点简单、重合较多的课程教材。会计专业中的《基础会计》和《财务会计》两本 教材根据实际教学过程中的总结, 可以进行合并整编为《财务会计基本原理及运用》，从而 实现进一步解放教学时间, 加大学生实操的相关比重; 同时也为分层分类培养提供了课程结构 上的合理性。

通过改革变化后, 能增强学生的获得感、成就感; 能提升学生的学习兴趣, 同时减轻学生 学习负担、压力。最终达到“所学必要用、要用必有学”的最佳职业培养目标。

\section{2 深入解析行业、岗位特性, 自主开发符合自身专业的针对性教材}

在深刻解析行业、岗位特性后，有针对性的开发符合自身专业特性的教材体系，已经是被 实践证明解决现有课程体系、教材体系行之有效的方法。通过校企结合、通过学校与专业职 能部门结合，开发一系列的专用教材可以解决如下的问题:

（1）通过自编教材解决教材缺乏行业针对性问题

在分层、分类教学模式下，在总的“财务会计”培养目标下，进一步细分为建筑业、制造业、 房地产业、物流运输业、电商、服务业等“行业财务会计”的具体目标。在此基础上让学生在 大一的第二学期进行自主选择喜好行业，以进行指向性、针对性的培养。

为了适应此教学模式的改革, 在联合行业专家、岗位能手的基础上, 自编对应的行业会计 专用教材。此类教材的核心要求是, 把通用的会计理论和方法结合行业自身的特殊知识和技 能要求, 系统的、行业整体的进行阐述。必须要达到通过行业专用教材的学习让学生掌握并 精通该行业财务会计的所有理论和实操技能，以真正实现学生的“专才”特质。

(2) 通过自编教材解决教材呈现的知识体系不完整的问题

现有的高职财经类专业教材中，无论是理论还是实训教材都不涉及具体的相关职能部门的 流程部分, 即不涉及跨部门之间的相关知识, 这导致学生毕业时毫无相关经验。但用人单位 往往需求的是熟悉全流程的人才，这严重影响了毕业生的对口就业。

通过与税务、工商、银行等相关职能部门的深入交流, 聘请对应的行业专家与资深的财会 专业人士一起合编《职能部门实操守则》《职能部门工作流程实训》专用教材, 来实现学生 出校门之前就能就行会计岗位的全流程业务的学习与模拟实操。真正实现“座位”与“岗位”的 无缝对接。

（3）通过自编教材解决教材知识更新滞后的问题

会计行业特性决定了, 会计知识和相关要求必须紧跟国家相关政策法规的变化, 随着新的 经济形势、趋势和新的企业形式的不断更新, 会计的相关法律法规必然会频繁的变化以适应 经济发展的要求。国家规划教材从成本效益原则出发不可能针对细小的知识点变化而进行教 材的全面更新, 这与会计的教学和会计行业的特性必然会产生冲突。

而自编教材可以做到“随变随改、随改随印”, 因此能够让呈现在学生面前的知识是最新的、 最准确的知识。 


\section{3 全面剖析执业差错、违规、舞弊现象的根源, 从学生生活习惯、学习习惯、思维习惯和 工作习惯上入手，通过贯穿全学制的强制训练，促使学生养成合格的职业精神}

“忠诚、专业、精准” 是财会人员核心的职业准则和职业精神, 这与当前高职院校学生的主 流价值观、行为习惯和思维习惯有很大的差距; 社会需要高素养的职业人才, 对职业精神的 看重更甚于专业技能。由此对高职院校在职业精神的培养体系上、培养方法上提出了很高的 要求。

我们结合心里专家、高素质职业人和专业教学团队，共同创建了“精准训练游戏”、“抗干扰 训练游戏”、“抵制欲望训练游戏”、“错误修正训练游戏”等体系化游戏, 在学生日常的生活、 学习中培养学生的心里素质、行为习惯、职业习惯和自控能力。

通过邀请司法部门相关人员、犯罪人员、犯罪心里学家走进校园，以自身的专业知识和切 身的体会讲解舞弊、犯罪的心路历程; 通过自愿原则, 让学生体会失去自由的痛苦、恐惧。 以促使学生有意识的修正自身的行为和思想、促使学生对规则、法律的敬畏。

高职教育, 人才培养定位是方向, 课程体系是核心、教育模式是基础。结合区域特性、区 域经济的发展和社会对人才的需求变化, 以国家规划教材为框架, 以自身的办学规模、学生 实际情况、教育模式为前提，科学合理规划自身教材体系是当前高职院校适应发展的必然进 程。自主开发、完善并形成适应国家要求、社会需求、行业需要的, 适应院校自身发展的, 独具特色的专业课程体系, 是高职院校品牌建设、核心专业建设的必然结果。

\section{[参考文献]}

[1]温家宝.大力发展中国特色的职业教育 在全国职业教育工作会议上的讲[N].中国教 育报,2005-11-04.

[2] 教育部,财政部.关于实施国家示范性高等职业院校建设计划加快高等职业教育改革与发展 的意见 [Z].教高[2006]14 号,2006-11.

[3]蔡炎斌.高等职业教育人才培养模式研究[M].长沙:湖南人民出版社,2006.

[4] 教育部.关于全面提高高等职业教育教学质量的若干意见[Z].教高[2006]16 号,2006-11.

[5] 吴文俊.推陈出新始能创新[N].文汇报，2007-11-14.

[6]安黎黎.探析影响学校教学改革的因素[J].考试周刊, 2009,(40).

[7]程荣福.高等职业教育教材改革与建设[J].职业教育, 2010,(11).

[8] 孙俊玲.高职教育教学改革的探索与思考[J].社科纵横, 2010,25(2):257-258.

[9]关远见.直面高等职业教育的思考[M].北京：线装书局，2007.

[10]眭平.基于应用创新性人才培养的创新教育实践 [J].中国高教研究，2013（8）:89-92.

[11]莫振达.基于实践模式的高职院校创业教育课程教学改革[J].学园,2015,5(03):74-75.

[12]丁金昌.实践导向的高职教育课程改革与创新[J].高等工程教育研究,2015(01):119-124.

[13] 邵景干, 师素云. 高职院校教学改革应注重学生创新能力培养 [J]. 科技视 界,2016(02):226+267.

[14] 孙卫敏.影响高职高专教育教学质量的因素与对策 $[\mathrm{J}]$. 长沙铁道学院学报（社会科学版）, 2011 (2):82-83.

[15]张煜.影响高职教学质量的因素与对策分析[J].人才资源开发, 2016（6）:230.

[16]黄慧文.探究高职院校财务会计教学改革的路径选择分析[J].职业教育, 2016. 
[17]文丰安.“产学结合”与“工学结合”解读.中国高教研究，2012（08）.

[18]田习洪.高职院校校企合作的实践与创新[J].产业与科技论坛.2013 年 06 期.

[19]王冲, 刘锦翠. 内涵建设背景下高职教师教育教学能力提升研究 [J]. 职教通讯, 2014(32):42-45. 